European journal of American studies

1-1 | 2006

Spring 2006

\title{
American Studies in Austria
}

\section{Susanne Mettauer}

\section{(2) OpenEdition}

\section{Journals}

Electronic version

URL: https://journals.openedition.org/ejas/212

DOI: 10.4000/ejas. 212

ISSN: 1991-9336

\section{Publisher}

European Association for American Studies

\section{Electronic reference}

Susanne Mettauer, "American Studies in Austria", European journal of American studies [Online], 1-1 | 2006, document 2, Online since 11 January 2006, connection on 14 July 2021. URL: http:// journals.openedition.org/ejas/212 ; DOl: https://doi.org/10.4000/ejas.212

This text was automatically generated on 14 July 2021

Creative Commons License 


\title{
American Studies in Austria
}

\author{
Susanne Mettauer
}

1 American Studies in Austria in an institutionalized form, as a distinct entity within higher education, is about to celebrate its $50^{\text {th }}$ anniversary. The Amerika-Institut in Innsbruck was founded in 1956, an effort that was greatly supported by the official United States. The local Amerika-Haus, a United States Information Center, was closed and the complete reference section of its library, including scholarly journals, was handed over to the university and the new institute. The latter did not yet conduct American Studies in a scholarly sense, but one of its main functions represented the American Studies approach in the broadest sense: providing access to much needed upto-date resource materials for subjects all across the academic curriculum, that is, regardless of the boundaries of the traditional disciplines and faculties.

2 The study of America as a scholarly discipline of its own benefited in particular from the Fulbright program, which has brought a wide range of American professors to Austrian universities. These scholars came from many academic fields, but in some way or other, they all contributed to and facilitated the local teaching, research, and knowledge about U.S. civilization and culture. Prior to the mid-1950s, these concerns were found in the university curricula and lecture courses only marginally and sporadically. In the post-World War II era, due to the increased activities of U.S. public diplomacy as well as the acknowledgment of the significance of this subject, the study of the United States. saw a rapid growth in Austria. Again, it was the United States who, in its own interest much more than for the mere sake of scholarly ideals, helped to make this development possible. An agreement between the United States and Austria determined that a certain amount of the counterpart funds that resulted from European Recovery Program ("Marshall-Plan") activities in Austria was to be earmarked for the establishment of professorships in American Studies at the universities of Innsbruck, Graz, and Vienna. Material and ideological support from the U.S. Embassy and the Austrian-American Educational Commission ("Fulbright Commission") has remained crucial in securing American Studies interests ever since. Today there are independent American Studies departments at the universities of Innsbruck and Graz. In Vienna, Salzburg, and Klagenfurt there are combined departments of English and American Studies. All five institutions have professors of 
American Studies and/or Literature. Attempts to establish a chair in American History have not been successful, even though particularly the History departments in Vienna and Salzburg have a strong tradition of research and teaching in this field.

Similarly, efforts to establish American Studies as an independent degree program have not been realized yet. Still, the field has come a long way on which it had to overcome the often strong opposition and prejudice of the "mother discipline," English Studies, as they competed for resources, personnel, students, and prestige. Presently, all five Austrian universities mentioned above offer a study course "English and American Studies," either toward a general academic diploma or a teaching degree for secondary schools, in which case it has to be combined with a second subject. Within these study courses, American Studies is a compulsory component and equal to English Studies. Students are required to study the literature and culture of both the United States. and Great Britain, with the option of choosing an area of concentration. Linguistics tends to emphasize the British point of view and treat American varieties and developments as appendices rather than course topics in their own right. Language proficiency courses too are usually connected to the English Studies departments or departmental subdivisions. Therefore it may not be a coincidence that certain prejudices and stereotypes concerning American speech still prevail, however subtly and informally.

This common pairing and parallelization of English Studies and American Studies in the university curriculum results in the frequent misperception that the two disciplines are basically the same: same language, same structural break-down, same methodologieseven the differences between the two countries are often represented as minimal due to their shared history and organic relations. This apparent homogeneity is particularly dangerous because of the numerical superiority and more entrenched status of English philology. No wonder that the reabsorption of American Studies by English Studies has been a real and serious threat ever since the former established itself. Apparently American Studies has had difficulties to present its interdisciplinary nature and potential to a wider, not immediately involved audience. Primarily, that is the case because this multi-pronged approach cannot be fully and visibly realized within the current university curriculum, that is, in the combination of English and American Studies. There may be room for individual specializations, for example film studies, media studies, gender studies, or cultural theory/studies, in the form of coherent modules within the degree program. Yet, however comprehensive and systematic such modules may be in the context of their own subarea, they do not and cannot represent the systematic study of U.S. civilization as a whole that American Studies proper signifies.

5 Therefore, at least on the curricular level, the study of America in Austria still awaits its full realization. Although it is possible to complete a Ph.D. program in American Studies, this specialization is not really sufficient, especially in consideration of the relatively small number of students who go on to attain a doctoral degree. The implementation of the EU-wide Bologna process, that is, the introduction of a threetier academic grade model instead of the traditional two-cycle system (Magister and doctorate), would theoretically mean an opportunity to design specific degree programs in American Studies on an earlier level than the doctorate. of course such a development mainly hinges on the availability of funding, and even that does not guarantee a consensus on the part of the university management concerning the basic desirability of such programs. On the one hand, a systematic knowledge and 
understanding of North America quite obviously have low priority in today's Austria, especially when a great number of people either feel or seem to be competent enough to make judgments themselves, and actual events as reported by the media apparently confirm the popular sentiment and preconceived notions about the United States. On the other hand, American Studies as a discipline, like almost all the humanities, faces the challenge of being measured and evaluated by criteria that are dictated by the world of business and economic interests, and that are therefore hardly applicable to endeavors oriented toward ideals of education and independent inquiry.

In spite of these institutional and structural obstacles, many individual Austrian scholars have explored the full range of American Studies, and for over three decades they have been represented by a professional academic organization. In 1974, a group of Austrian Americanists got together in Schloss Leopoldskron, Salzburg, to found a national Association for American Studies, which in 1976 also became a member of the European Association for American Studies. Today, the AAAS has around 100 members with a variety of academic affiliations. It publishes an annual newsletter and the American Studies in Austria series. The chairmanship of the association rotates every year between the respective departments in Klagenfurt, Vienna, Graz, Salzburg, and Innsbruck. The presiding institution is responsible for organizing that year's AAAS conference, which also serves as the general meeting. Conference topics of the past years were, "The EmBodyment of American Culture" (2001), "(Anti)Americanisms" (2002), "U.S. Icons and Iconicity" (2003), and "Race, Culture, and the Dynamics of Change" (2004). The 2005 conference was going to take place in New Orleans and examine the many facets of "The South, New Orleans, the Caribbean, and Discourses of Creolization." The meeting was meant to contribute to the international outreach of the AAAS as well as to the diverse activities under the long-standing friendship agreement between the University of Innsbruck (which currently holds the AAAS presidency) and the University of New Orleans. However, with the program and workshops fully set up and most arrangements already made, the conference had to be cancelled eventually, due to the devastation caused by Hurricane Katrina and its aftermath. Consequently, the 2005 meeting will only consist of a board meeting and a general assembly without the usual keynote lectures, papers, and scholarly discussions.

7 A regular element of AAAS conferences has been the graduate student forum in which students with a research interest in American Studies present their theses, whether completed or still in progress. The lively participation in these events testifies to the strong appeal of American Studies to young scholars, and to the many ways in which the subject offers considerable relevance to their lives. A glance at the current list of M.A. and doctoral theses compiled in the AAAS Newsletter suggests the full potential of the field of American Studies and includes such diverse topics as guitar blues, the New York City marathon, Arab American memoirs, or "Mark Twain Meets The Simpsons." Every year, the most outstanding thesis is acknowledged by the Fulbright Prize in American Studies. This award is sponsored by the Austrian-American Educational Commission, managed by the AAAS, and amounts to $€ 1,000$.

8 One reason for the impressive number of American Studies theses is arguably the fact that many students are taking advantage of exchange programs and research grants to study in and thus experience the United States first-hand. The internationalization of Austrian American Studies fostered networking and institutional cooperation and led to numerous exchange programs, both university-wide and on a departmental level. 
The University of Salzburg has ties with the universities of Utah and Minnesota, to name but two. Graz has joint-study agreements with the universities of Little Rock and Oklahoma, in addition to more than a hundred U.S. universities that participate in the International Student Exchange Program (ISEP), of which the University of Graz is a member. Innsbruck, finally, signed friendship treaties with the University of Notre Dame, Utah State University, and the University of New Orleans. Under the latter agreement, more than forty Austrian students a year study in Louisiana, which makes this the single largest exchange program in the country, even exceeding the total number of American Fulbright students coming to Austria every year. Apart from university exchange programs, student and faculty mobility in Austria and the U.S. is greatly enhanced by the Fulbright program which offers exchange opportunities in both directions, thereby truly realizing Senator Fulbright's idea of fostering mutual understanding and goodwill. Fulbright grants are open to students, professors, researchers, and teachers from all academic disciplines, a feature that also applies to many university exchange programs. This further emphasizes the inter- and multidisciplinary character of American Studies.

There are also numerous study abroad opportunities at other European universities which have an American Studies focus. Regional and inter-European networks and cooperations are just as important as transatlantic connections and help Americanists here to build a distinct profile. In the past, Austria was twice the center of crucial developments in European American Studies. In 1947, the first Salzburg Seminar in American Studies took place at Schloss Leopoldskron. The Schloss is also the birthplace of the European Association for American Studies, which was founded there in 1953. The location of Austria in the heart of Europe may turn out to be an advantage once more, as the European intellectual scene is greatly expanding and Eastern European universities are being integrated into the existing scholarly network. The University of Graz, for instance, has a well-established friendship agreement with the University of Maribor. Another indication of the promising position of Austria in this regard is the increasing participation of young Americanists from Eastern Europe at AAAS conferences.

10 Quite obviously, American Studies in Austria is a rich, engaging field with great potential, increased possibilities, strong attraction, and above all very motivated and innovative people. However, it is often very frustrating when this potential is thwarted and possibilities limited by current developments in the educational sector. The most serious factor is the reduction of funding, and that the reduced budget is allotted on the basis of criteria which, as already mentioned, do not favor the humanities. The absorption and/or limitation of American Studies by English departments is a scenario that looms large at all five universities. At the University of Salzburg, the Department of English and American Studies was renamed and is now called Fachbereich Anglistik in which "American Literary and Cultural Studies" is one of several subdivisions. In Innsbruck, the new development plan that was proposed by the rector and is currently under debate in the responsible committees, envisions a fusion of the American Studies with the English Studies department. The American Studies faculty strongly opposes this plan and insists that its idea of American Studies would suffer from a joint department in which English Studies would be much more dominant. One effect of the debate about the future of the discipline has been a heightened concern with the contemporary nature and function of American Studies, and completely new projects 
are in the air. Without a doubt, American Studies in Austria will be able to thrive also in the future, in both traditional and innovative forms.

INDEX

Keywords: Amerika-Haus, Salzburg Seminar, Slovenia, Fulbright, Icons, Creolization, New Orleans, AAAS

\section{AUTHOR}

SUSANNE METTAUER

University of Innsbruck 